\title{
Human security and the stabilization mandate of MINUSCA
}

Article

Accepted Version

Gilder, A. ORCID: https://orcid.org/0000-0002-8861-1433 (2021) Human security and the stabilization mandate of MINUSCA. International Peacekeeping, 28 (2). pp. 200-231. ISSN 1353-3312 doi:

https://doi.org/10.1080/13533312.2020.1733423 Available at https://centaur.reading.ac.uk/101394/

It is advisable to refer to the publisher's version if you intend to cite from the work. See Guidance on citing.

To link to this article DOI: http://dx.doi.org/10.1080/13533312.2020.1733423

Publisher: Routledge

All outputs in CentAUR are protected by Intellectual Property Rights law, including copyright law. Copyright and IPR is retained by the creators or other copyright holders. Terms and conditions for use of this material are defined in the End User Agreement.

\section{www.reading.ac.uk/centaur}

\section{CentAUR}

Central Archive at the University of Reading 
Reading's research outputs online 
The Version of Record of this manuscript has been published and is available in International Peacekeeping http://www.tandfonline.com/10.1080/13533312.2020.1733423

\title{
Human security and the stabilization mandate of MINUSCA
}

\author{
Alexander Gilder \\ Royal Holloway, University of London, UK
}

\begin{abstract}
This article looks narrowly at whether a 'human security' approach can be seen in a UN peace operation that pursues stabilization, namely the United Nations Multidimensional Integrated Stabilization Mission in the Central African Republic (MINUSCA). The UN's interpretation of stabilization has not been expressly set out, but stabilization missions typically work alongside the host state to extend state authority and use robust force to counter spoilers. Human security is a concept which is rights-based, promotes the 'vital core', has a concern for vulnerability, utilises preventative protection methods, and empowers local persons to have agency in the peace process. Attempts have been made to institutionalise and mainstream human security practices within the UN. An analytical framework of human security is outlined in this article and used to assess to what extent the mandate of MINUSCA pursues human security-based goals. An extensive review of UN documentation looks at the mandate and practice of MINUSCA and it is argued that the mission does seek to empower local people, engage in a bottom-up manner and entrench the rule of law. The analytical framework also casts light on aspects of the stabilization mandate which are problematic such as militarisation and cooperation with the host state.
\end{abstract}

\section{Keywords}

Human security - UN peacekeeping - stabilization - militarization - Central African Republic

\section{$1 \quad$ Introduction}

Over the past two decades there have been numerous attempts to institutionalise the concept of 'human security' at the United Nations (UN). ${ }^{1}$ During a similar period, UN peace operations have evolved into a new beast, one which holds the protection of civilians and sustainable, inclusive peace as paramount priorities. More recently though, the Security Council has further developed a new priority stabilization. Stabilization has not been defined by the UN nor has it been consistently expounded in mission mandates. ${ }^{2}$ In 2015 the High-Level Independent Panel on Peace Operations (HIPPO) stated the

\footnotetext{
${ }^{1}$ For instance, the UN Human Security Unit was created in 2004 with the purpose of mainstreaming human security in all UN activities. Also, the UN General Assembly has held thematic debates on the topic and adopted a definition of human security in 2012. See UN, A/RES/66/290 (2012); Thérien, "Human Security: The Making of a UN Ideology."

${ }^{2}$ High-Level Independent Panel on UN Peace Operations, Uniting Our Strengths for Peace; Aditi Gorur, "Defining the Boundaries of UN Stabilization Missions."
} 
The Version of Record of this manuscript has been published and is available in International Peacekeeping http://www.tandfonline.com/10.1080/13533312.2020.1733423

term has a wide range of interpretations and the UN's usage needs clarification. ${ }^{3}$ The adoption of stabilization has been said to be a 'hodge-podge' of words and "[t]he danger is that the terminological imprecision surrounding 'stabilization' creates a meta-category; full of buzzwords but empty of meaning." ${ }^{4}$ Generally speaking, UN stabilization missions typically do two things. First, they displace and deter armed groups and, second, undertake peacebuilding activities to entrench state authority and create state legitimacy in the power vacuum left behind. ${ }^{5}$ Both of these actions are intended to extend state authority, with the displacement of armed groups achieved through the 'robust' use of force by UN troops followed by civilian-led peacebuilding activities. ${ }^{6}$

The question this article seeks to answer is, to what extent does the stabilization mandate of the United Nations Multidimensional Integrated Stabilization Mission in the Central African Republic (MINUSCA) resemble a human security-based strategy? Without a clear definition it is important to ascertain what underpins the UN's approach to stabilization. It may be the case that practices used in a stabilization mission are in fact akin to human security. Human security is an important concept for UN peace operations generally since it seeks to understand the context and nuances of a conflict from the bottom-up which is essential for the effectiveness of a mission. ${ }^{7}$ There are also temporal reasons for this choice as the development of the concept of human security is temporally aligned with the emergence of peace operations with complex multidimensional activities and the inclusion of protection of civilian (PoC) mandates in the early 2000s. ${ }^{8}$ More recently, stabilization has begun to take a more 'robust' approach to $\mathrm{PoC}$ which may indicate a commitment to human security. This paper argues the human security concept is based upon five principles; (1) human rights and the rule of law, (2) a focus on the vital core identified in a bottom-up manner, (3) a concern for vulnerability and building resilience, (4) preventative protection, and (5) the empowerment of people to act on their own behalf and implement solutions to security threats.

The five principles serve as an analytical framework to be used in the discursive analysis of MINUSCA's mandate and accompanying reporting to demonstrate how the UN frames its activities. This analytical framework can serve as a tool to deepen our understanding of mission mandates and explores potential linkages of contemporary peacekeeping practice with the broad goals advanced by human security. The study is based on an extensive review of public UN documentation and therefore

\footnotetext{
${ }^{3}$ High-Level Independent Panel on UN Peace Operations, Uniting Our Strengths for Peace, para 114.

${ }^{4}$ Mac Ginty, “Against Stabilization,” 24.

${ }^{5}$ See e.g. Gilder, "The Effect of 'Stabilization' in the Mandates and Practice of UN Peace Operations"; Tull, "The Limits and Unintended Consequences of UN Peace Enforcement"; de Coning et al., "Towards a United Nations stabilization doctrine - stabilization as an emerging UN practice".

${ }^{6}$ There are a number of recent discussions surrounding the increased use of force by UN peacekeepers to combat terrorism and what robustness means in practice. See e.g. Karlsrud, The UN at War; de Coning, "Is stabilization the new normal?"; Karlsrud, "From Liberal Peacebuilding to Stabilization and Counterterrorism"; Kjeksrud et al., "Protecting governments from insurgencies".

${ }^{7}$ For a discussion of the importance of context see Hanlon and Christie, Freedom from Fear, Freedom from Want, 32-3.

${ }^{8}$ Fortier, "The Evolution of Peacekeeping"; Golberg and Hubert, "The Security Council and the Protection of Civilians".
} 
The Version of Record of this manuscript has been published and is available in International Peacekeeping http://www.tandfonline.com/10.1080/13533312.2020.1733423

cannot paint the full picture of how the mandate is interpreted and operationalised in practice. Future research could build on the application of this framework to further assess whether the UN is in fact pursuing a human security-based agenda in the field. Nevertheless, there are lessons to be learnt from how activities are framed in Security Council meetings and Secretary-General reporting, for instance, and whether they embody the operationalisation of human security. The article more generally contributes to the literature on human security because few other attempts have been made to assess the implementation of the concept. It is argued that MINUSCA does seek to achieve some of human security's goals under the guise of the UN's peacebuilding agenda, such as empowering local people, engaging in a bottom-up manner and entrenching the rule of law. The analytical framework also casts light on aspects of the stabilization mandate which are problematic for peacebuilding such as militarisation and UN cooperation with the host state.

\section{The principles of human security}

The concept of human security seeks to shift the referent object of security from the state to the individual by challenging realist views and giving the individual intrinsic value. Where the individual's interests compete with that of the state or society, the former should be given priority. The UN Development Programme (UNDP) coined the term in their 1994 Human Development Report building on the earlier goal of achieving freedom from fear and want found in the Preamble of the Universal Declaration of Human Rights. The Report attempted to create a vision of human security that could be adopted by states and the UN in furthering social development. ${ }^{9}$ The team behind the Report sought to create an approach that focused on issues such as poverty, disease, threats of violent conflict, and restrictions on political freedom. ${ }^{10}$ Following the 1994 UNDP Report various middle powers including Canada, Norway and Japan adopted human security approaches in their foreign policies. ${ }^{11}$ In 2001 the Commission on Human Security was created by UN Secretary-General Kofi Annan and published its Human Security Now Report two years later. ${ }^{12}$ The Commission defined human security as:

to protect the vital core of all human lives in ways that enhance human freedoms and human fulfilment. Human security means protecting fundamental freedomsfreedoms that are the essence of life. It means protecting people from critical (severe) and pervasive (widespread) threats and situations. It means using processes that build on people's strengths and aspirations. It means creating political, social, environmental, economic, military and cultural systems that together give people the building blocks of survival, livelihood and dignity. ${ }^{13}$

\footnotetext{
${ }^{9}$ UNDP, Human Development Report 1994, 24.

${ }^{10}$ Acharya, "Human Security," 449.

${ }^{11}$ Farer, "Defining the Elephant and Imagining Its Tasks," 46.

${ }^{12}$ Commission on Human Security, Human Security Now.

${ }^{13}$ Commission on Human Security, Human Security Now, 4.
} 
The Version of Record of this manuscript has been published and is available in International Peacekeeping http://www.tandfonline.com/10.1080/13533312.2020.1733423

The definition places a focus on pervasive and widespread threats in an attempt to narrow human security to the core threats to survival and make the concept more practical for operationalisation. ${ }^{14}$ The principles expounded below are based upon the Commission's modelling of human security and draw out five core elements of what human security includes.

Paris has argued that human security is a concept which is not useful for policymaking because its competing policy goals are too difficult to reconcile and a further author stated it "has so far proven largely unworkable in practice." ${ }^{15}$ However, the Commission on Human Security took a distinct focus on humanitarian crisis and conflict alongside emphasising that the methods advanced by human security respect and simply put into practice existing international legal norms such as those within international human rights and humanitarian law. For instance, the Commission argues a rights-based human security approach "reorients humanitarian strategies towards enhancing people's capabilities, choices and security." 16 The Commission sought to present human security as a tool with which to guide activities during and after conflict. Concurrently, UN peace operations have developed in the 21 st century to include a range of peacebuilding activities which support the development of both the state as a whole and communities at the local level. Peace operations engage with communities on a daily basis and are mandated to support elections, address sexual violence, support refugees and internally displaced persons with reintegration into local communities, and undertake a range of projects aimed at improving local services and rebuilding the capacity of local, regional, and national government bodies to carry out necessary functions of the state. The literature on human security is rich and definitions are abound which cannot be engaged with in the space allotted here. Consequently, an analytical framework based upon the Commission's Human Security Now Report sufficiently narrows the scope of the study but has been chosen because the Report aligns temporally, was commissioned by the Secretary-General, and shares with UN peace operations a focus on humanitarian crisis and conflict.

\subsection{Human rights and the rule of law}

It is accepted that the rule of law, respect for international legal norms such as those within human rights and humanitarian law, accountability through the law, and good governance are inherent to human security. ${ }^{17}$ The Commission on Human Security, when discussing the importance of existing international law, made the rights-based character of human security clear. ${ }^{18}$ International law in general "must be at the heart of human security" and the latter is constructed from the fragmented disciplines

\footnotetext{
${ }^{14}$ Alkire, "A Vital Core that Must Be Treated with the Same Gravitas as Traditional Security Threats," 360.

${ }^{15}$ Paris, "Human Security: Paradigm Shift or Hot Air?" 88; Chappuis, "Human Security and Security Sector Reform," 99.

${ }^{16}$ Commission on Human Security, Human Security Now, 27.

${ }^{17}$ Daft, The Relationship Between Human Security Discourse and International Law, 5.

${ }^{18}$ Commission on Human Security, Human Security Now, 28.
} 
The Version of Record of this manuscript has been published and is available in International Peacekeeping http://www.tandfonline.com/10.1080/13533312.2020.1733423

of human rights law, humanitarian law, international criminal law, and refugee law. ${ }^{19}$ International law serves as a basic criteria with which to strengthen work on human security's objectives. ${ }^{20}$

The Human Security Now Report has a focus on protecting people in violent conflict where the authors say that "[p]rotecting human rights and upholding humanitarian law are essential to human security in conflict situations." 21 The Commission explains human security can be used to identify the rights at stake in a particular situation which demonstrates how the former can enrich existing normative rights. ${ }^{22}$ For example, using human security's other principles it can be assessed which rights are most threatened and empowerment strategies can be used to build the capacity of those affected to be resilient to security threats. The report argues for integrated strategies that protect people and are mutually reinforcing with specific attention for vulnerable groups that require protection. ${ }^{23}$ At the core of this protection is promoting respect for the rule of law. ${ }^{24}$ When the international community undertakes actions aimed at protecting rights and promoting the rule of law, like by deploying a UN peace operation, it does so under existing normative frameworks. ${ }^{25}$ By grounding human security in those norms human security can be utilised to give a universal, coherent framework that focuses the attention of existing law on protecting individuals from immediate and pervasive threats identified by those affected. The threats concerned are identified by the vital core, discussed next.

\subsection{The vital core}

The Commission knew that it would be impossible and wholly impracticable for actors to look at all possible security issues relating to all individuals and groups, therefore a solution was needed. ${ }^{26}$ The solution was the creation of a variable 'vital core' which is described as what people hold to be the 'essence of life' and 'crucially important'. ${ }^{27}$ The vital core is able to shift the focus on a needs basis for different individuals and groups.

The Commission's definition of human security includes the protection from "critical (severe) and pervasive (widespread) threats and situations". ${ }^{28}$ There is not an exact definition of what can constitute a critical threat to avoid top-down decisions on which considerations are most critical to the essence of life for all people. ${ }^{29}$ Instead, the vital core can vary depending on the individuals and groups affected, to take into consideration what they believe to be the essence of their lives be it a political,

\footnotetext{
${ }^{19}$ Chinkin et al., International Law and New Wars, 565.

${ }^{20}$ Hanlon and Christie, Freedom from Fear, Freedom from Want, 55.

${ }^{21}$ Commission on Human Security, Human Security Now, 28.

22 ibid. 10.

${ }^{23}$ Commission on Human Security, Human Security Now, 134.

24 ibid. 134.

${ }^{25}$ See e.g. UN, ST/SGB/1999/13 (1999); UN, A/68/19 (2014), para. 212; UN, A/46/185 (1991), para 28.

${ }^{26}$ Ogata, "From State Security to Human Security," 4.

${ }^{27}$ Commission on Human Security, Human Security Now, 4.

28 ibid. 4

${ }^{29}$ Alkire, “A Conceptual Framework for Human Security,” 9.
} 
The Version of Record of this manuscript has been published and is available in International Peacekeeping http://www.tandfonline.com/10.1080/13533312.2020.1733423

economic, environmental or another issue. In this way security is personalised and not rigid based on what the international community, and consequently states, determine to be the most critical and pervasive threats.

When applying human security as an analytical framework the vital core is interpreted as whether or not the actors seeking to provide security have sought to consult individuals concerned on what they hold to be 'crucially important' for security and well-being. Hanlon and Christie have made similar observations explaining "insights from grassroots civil society organizations must reach the desks of top-down development planners. Only through continuous stakeholder dialogue involving a range of both local and international actors can peacebuilding achieve meaningful results" that provide positive human security improvements. ${ }^{30}$ The concept of human security does not have a predetermined hierarchy of threats. Rather than having a predetermined hierarchy dictated by the international community on what is seen as the most effective course of action for the globe, the international community instead considers the most prevalent needs of individuals and communities in each threatened location. For instance, a predetermined hierarchy could suggest a threat to political security is the second most important after the threat of violence from armed groups but for many communities food scarcity or infant mortality could be much more prevalent concerns than physical violence.

The vital core and human security's lack of a predetermined hierarchy of threats is part of what gives human security its exclusive character. By adopting a framework that requires international actors to seek views of individuals and groups on what those people feel are the key factors undermining security the international actor concerned can provide a response which will lead to meaningful improvements. That is to say, the effectiveness of interventions will be enhanced and more able to provide tangible improvements that are desired by the persons affected.

\subsection{Vulnerability}

Human security recognises vulnerability as a crucial factor in decision-making. The Commission expressly calls for concern for people on the move and for women, children, the elderly, the disabled, the indigenous, and the missing. In addition, the UN General Assembly, when defining human security, declared that "[a]ll individuals, in particular vulnerable people, are entitled to freedom from fear and freedom from want". ${ }^{31}$ Due to the attention given to vulnerability by the human security discourse it necessarily forms one of the principles of the concept for the analytical framework.

There is a rich body of work on vulnerability and notably the work of Fineman has argued that identifying specific vulnerabilities can be stigmatising. ${ }^{32}$ For the purposes of this work it is simply suggested that some individuals or groups are more vulnerable than others and should be identified by

\footnotetext{
${ }^{30}$ Hanlon and Christie, Freedom from Fear, Freedom from Want, 107.

${ }^{31} \mathrm{UN}, A / R E S / 66 / 290$ (2012), para. 3(a) (emphasis added).

${ }^{32}$ Fineman, "Vulnerability, Resilience, and LGBT Youth," 315
} 
The Version of Record of this manuscript has been published and is available in International Peacekeeping http://www.tandfonline.com/10.1080/13533312.2020.1733423

international actors. For instance, Tobin suggests that the fact all humans are in some way vulnerable should not obscure that some are more vulnerable than others due to many different factors. ${ }^{33}$ For the application of this analytical framework, there needs to be clear identification of particular vulnerabilities. A human security approach could be evident if categories of persons are identified as being at particular risk.

Fineman argues that the partial antidote to vulnerability is resilience which is defined as "what provides an individual with the means and ability to recover from harm or setbacks." ${ }^{34}$ The ability to be resilient and build further resilience is determined by the level of resources a person has access to. The actions taken by an international actor must contribute to building resilience to evidence a concern for human security, as opposed to identifying a vulnerability and taking short-term action which leaves the root cause of the vulnerability intact.

\subsection{Protection and empowerment}

The principles of protection and empowerment form one overarching and interlinked strategy. First, it is recognised that people require protection from a range of threats, not only physical harm, and responses must be preventative where possible with a long-term vision in mind. Second, empowerment strategies must ensure institutions, communities, and individuals are resilient and able to identify and address security threats locally where possible and be given a voice at regional, national and international levels to raise security issues.

The Human Security Now Report states,

To protect people - the first key to human security — their basic rights and freedoms must be upheld. To do so requires concerted efforts to develop national and international norms, processes and institutions, which must address insecurities in ways that are systematic not makeshift, comprehensive not compartmentalized, preventive not reactive. Human security helps identify gaps in the infrastructure of protection as well as ways to strengthen or improve it. ${ }^{35}$

The protection element means that an intervention should, where possible, be preventative and not simply fight fires and respond after, for example, an attack on a town by an armed group, but instead will take the initiative to ensure the security of individuals from known threats before catastrophe strikes. Interventions such as the deployment of a peace operation is a top-down action and what the international community feels is needed to 'shield people' and create structures that ensure the rule of law and democratic engagement. ${ }^{36}$ However, under a human security approach protection cannot be merely from threats of physical violence and broader considerations are needed including for instance,

\footnotetext{
33 Tobin, “Understanding Children's Rights," 164.

${ }^{34}$ Fineman, "Vulnerability, Resilience, and LGBT Youth," 320.

${ }^{35}$ Commission on Human Security, Human Security Now, 11.

${ }^{36}$ Ogata, "The Human Security Commission's strategy," 25-6.
} 
The Version of Record of this manuscript has been published and is available in International Peacekeeping http://www.tandfonline.com/10.1080/13533312.2020.1733423

health crises, water shortages, financial crisis or pollution. ${ }^{37}$ Many threats to human security that require protection will stem from conflict but not all will, and the international community cannot only see protection as ensuring physical integrity when utilising a human security approach.

The empowerment aspect of the Commission's framework is thought to have the most potential and is argued to show how human security can respond to crises in a more legitimate and focused way than existing security practices. ${ }^{38}$ Empowerment is, “[p]eople's ability to act on their own behalf-and on behalf of others..." ${ }^{39}$ Where people require protection, or have been protected, they can identify and implement solutions to security threats. ${ }^{40}$ To do so requires resilience where people empowered can "create new opportunities for work and address many problems locally. And they can mobilize for the security of others - say, by publicizing food shortages early, preventing famines or protesting human rights violations by states." ${ }^{41}$

It is through bottom-up engagement where individuals in society are able to identify and communicate their needs to a range of actors. Where people are adequately protected, they can be empowered to "make better choices, and actively prevent and mitigate the impact of insecurities." 42 The two strands of protection and empowerment are core to human security's novelty. They are mutually reinforcing where "[p]eople protected can exercise many choices. And people empowered can avoid some risks and demand improvements in the system of protection." ${ }^{43}$ A human security approach by the UN requires the facilitation of empowerment particularly where individuals have been forced to build their own security regimes within communities because the state is unwilling or unable to provide security. ${ }^{44}$ A UN peace operation that is utilising elements of a human security approach will ensure protection from more than only threats of violent conflict and first and foremost take preventative steps to address a range of security issues. In addition, empowerment will be facilitated by creating space for local people to identify the causes of insecurity, implement strategies to counter those causes, and leave behind people who can bring about change in their own societies when insecurity arises.

\section{$3 \quad$ Human security in MINUSCA}

\subsection{Human rights and the rule of law}

MINUSCA's first mandate in April 2014 included a host of rights and norms-based provisions. The mandate stresses the need to end impunity for violations of international law either within the national

\footnotetext{
${ }^{37}$ Commission on Human Security, Human Security Now, 11.

${ }^{38}$ Ogata, "From State Security to Human Security," 5.

${ }^{39}$ Commission on Human Security, Human Security Now, 11.

40 ibid. 6.

41 ibid. 11 .

${ }^{42}$ Ogata, "The Human Security Commission's strategy," 26.

${ }^{43}$ Commission on Human Security, Human Security Now, 12.

${ }^{44}$ Hanlon and Christie, Freedom from Fear, Freedom from Want, 62
} 
The Version of Record of this manuscript has been published and is available in International Peacekeeping http://www.tandfonline.com/10.1080/13533312.2020.1733423

legal system or before the International Criminal Court. ${ }^{45}$ To assist the transitional authorities in that endeavour, MINUSCA was to monitor and report on violations of humanitarian law and human rights and to work on preventing future violations by utilising human rights observers. ${ }^{46}$ Furthermore, ending impunity would be particularly difficult where the ex-Séléka are in control of government functions. MINUSCA was mandated to extend state authority and to build the capacity of the judicial system and reinstate the criminal justice system "within the framework of the United Nations global focal point on rule of law" ${ }^{47}$ From the mission's inception there was an understanding that for an effective state the rule of law needed to be re-established. Since 2014 the mission has worked on the reform of the police and gendarmerie in compliance with the UN Human Rights Due Diligence Policy (HRDDP) and expanded its monitoring of violations to specifically focus on children and women in light of the sexual violence that has taken place throughout the Central African Republic (CAR). ${ }^{48}$

To re-establish the rule of law MINUSCA sought to support the reopening of courts, prisons, police stations, and related infrastructure. ${ }^{49}$ The mission would provide a secure environment for the operation of the criminal justice system to end impunity and ensure adherence to human rights law. ${ }^{50}$ This formed part of an overarching strategy for MINUSCA, and is seen to be vital to the success of the mission, where it was believed a) international forces would be more effective if the penal system was re-established and b) there must be development and respect of human rights and the rule of law if the CAR is to have peace. ${ }^{51}$ The CAR's legal system has been said to be 'dysfunctional' with a severe lack of resources. ${ }^{52}$ To rectify this, MINUSCA was granted urgent temporary measures under its mandate "to maintain basic law and order and fight impunity". ${ }^{53}$ These temporary measures are beyond the normal law enforcement capabilities of peace operations and are created without establishing precedent. ${ }^{54}$ In 2019 it was reported that the temporary measures were used to apprehend 54 persons on suspicion of crimes such as murder, kidnap, armed robbery, and torture. ${ }^{55}$

MINUSCA first deployed a team of investigation and prosecution experts to assist with investigations of serious violations of international law. ${ }^{56}$ At a later date, international prosecutors, judges and national magistrates would try the alleged perpetrators of violations. ${ }^{57}$ The resulting body to hold these trials is the Special Criminal Court mandated under MINUSCA's temporary measures in

\footnotetext{
${ }^{45} \mathrm{UN}, \mathrm{S} / \mathrm{RES} / 2149$ (2014), 2, para 12.

46 ibid. para 30(e)(i)

${ }^{47}$ ibid. para 30(f)(ii), 30(f)(iii).

${ }^{48} \mathrm{UN}, S / P V .7734$ (2016), 3 as per Mr. Ladsous; UN, S/RES/2387 (2017), para 43(d)(ii).

${ }^{49} \mathrm{UN}, \mathrm{S} / 2014 / 142(2014)$, para 76.

50 ibid. para 81; UN, S/RES/2387 (2017), para 43(e)(vi).

${ }^{51}$ UN, S/2016/565 (2016), paras 46-9; UN, S/PV.7206 (2014), 3 as per Mr. Gaye; UN, S/2014/142 (2014), para 10 .

${ }^{52} \mathrm{UN}, S / 2014 / 928$ (2014), para 56.

${ }^{53} \mathrm{UN}, \mathrm{S} / \mathrm{RES} / 2149$ (2014), para 40; UN, S/RES/2301 (2016), para 34(d)(i).

${ }^{54} \mathrm{UN}, \mathrm{S} / \mathrm{RES} / 2301$ (2016), para 34(d)(i).

${ }^{55} \mathrm{UN}, \mathrm{S} / 2019 / 147$ (2019), para 46.

${ }^{56} \mathrm{UN}, \mathrm{S} / 2014 / 562$ (2014), para 53.

57 ibid. para 54.
} 
The Version of Record of this manuscript has been published and is available in International Peacekeeping http://www.tandfonline.com/10.1080/13533312.2020.1733423

agreement with the Transitional Authorities. ${ }^{58}$ The Special Criminal Court has been criticised by the Russian delegation as having potential for extreme costs and inefficiency. ${ }^{59}$ Progress was slow, despite its inception in August 2014 it was not until June 2017 that a Special Prosecutor and five judges were sworn in and until May 2018 for rules of procedure and evidence for the Court to be adopted. ${ }^{60}$ The Court's first session was held in October 2018 and the first investigations supported by MINUSCA were launched in 2019. ${ }^{61}$ By October 2019 the Court had identified 22 priority cases and MINUSCA had created a "special legal corps' to "protect the rights of the accused." 62 What is notable though is that the mandate for providing support to the Court has been greatly shortened in the most recent iteration of MINUSCA's mandate. ${ }^{63}$ This may indicate that now the Court has been established it will develop further independence from the UN. Ending impunity through a court such as this is a way in which the Security Council can link the work of peace operations to wider agendas on international criminal justice and universal human rights.

In less than one year from the mission's deployment, courts in Bangui resumed their functions and magistrates were deployed to 12 out of 28 courts in other areas of the CAR. ${ }^{64}$ By 2017, civil cases were being adjudicated by mobile courts supported by MINUSCA and UNDP and criminal cases were being heard in Bangui. ${ }^{65}$ Prisons were reopened and MINUSCA was granted a number of corrections officers as part of its troop ceiling to assist with the training of CAR prison officers and improving prison standards. ${ }^{66}$

Despite MINUSCA's efforts on human rights and the rule of law as a priority task, there are still rampant abuses in the CAR. In one reporting period from 15 November 2017 to 15 February 2018, MINUSCA documented 1,283 abuses and violations of human rights and humanitarian law. ${ }^{67}$ The violations included attacks against schools, conflict-related sexual violence, killings, and cruel and inhuman treatment. ${ }^{68}$ The number of incidents documented represented an increase of $59 \%$ from the previous reporting period.

The work of MINUSCA on human rights and extending the rule of law forms a crucial part of its understanding of stabilization. The mission has taken up the mantle of revitalising the justice system in the wake of widespread human rights abuses and sexual violence perpetrated throughout the conflict. The temporary measures mentioned above are used without establishing precedent. ${ }^{69}$ However, if the

\footnotetext{
${ }^{58}$ UN, S/PRST/2014/28 (2014), p.4; UN, S/PV.7246 (2014), p.3 as per Mr. Gaye; UN, S/2014/928 (2014), para 63.

${ }^{59} \mathrm{UN}, \mathrm{S} / \mathrm{PV} .7901$ (2017), 11 as per Mr. Iliichev.

${ }^{60}$ Human Rights Watch, "Central African Republic: Parliament Adopts Special Criminal Court Rule."

${ }^{61} \mathrm{UN}, \mathrm{S} / 2019 / 498$ (2019), para 59.

${ }^{62} \mathrm{UN}, \mathrm{S} / 2019 / 822(2019)$, para 57.

${ }^{63}$ Contrast UN, S/RES/2448 (2018), paras 39(e)(v)-(xi) with UN, S/RES/2499 (2019), paras 32(e)(iv)-(v).

${ }^{64} \mathrm{UN}, \mathrm{S} / 2015 / 227$ (2015), para 47.

${ }^{65} \mathrm{UN}, \mathrm{S} / 2017 / 94$ (2017), para 48.

${ }^{66} \mathrm{UN}, \mathrm{S} / \mathrm{RES} / 2212(2015)$.

${ }^{67} \mathrm{UN}, \mathrm{S} / 2018 / 125$ (2018), para 51.

68 ibid.

${ }^{69} \mathrm{UN}, \mathrm{S} / \mathrm{RES} / 2149$ (2014), para 40; UN, S/RES/2301 (2016), para 34(d)(i).
} 
The Version of Record of this manuscript has been published and is available in International Peacekeeping http://www.tandfonline.com/10.1080/13533312.2020.1733423

Court is successful the use of similar arrangements in future mandates could prove desirable. What is concerning is whether other aspects of stabilization will undermine building the rule of law. From a human security standpoint basing the mission's responses on established principles of human rights and the rule of law is of crucial importance to provide a solid foundation for the rebuilding of the CAR's institutions. Although, these actions must be undertaken in concert with local people and with local concerns being addressed if there is to be faith restored in the system.

\subsection{Vital core}

The UN understands that in its early stages a peace operation must address urgent priorities and provide immediate dividends to the population..$^{70}$ For a human security approach those priorities and dividends must reflect the needs identified by the communities in question. The Secretary-General states, "[t]he work of the United Nations in the Central African Republic must be based on a clear understanding of the current situation and be tailored to the future needs of its people." ${ }^{71}$ It is therefore crucial that the UN's knowledge of the current situation is informed by local people. However, no detail is given on whether a particular priority task has been constructed directly from consultations with civil society, international partners, or the host state. What can be seen in the documentation is that both MINUSCA and representatives of the Security Council do discuss mission matters with a broad range of actors. For instance, during a strategic review of the mission the $\mathrm{UN}$ met with the government, civil society and women's groups to discuss the mission priorities. ${ }^{72}$ In March 2015, a Security Council mission to the CAR spoke to local authorities, magistrates, the police and gendarmerie, civil society, religious leaders, and ex-Séléka representatives. ${ }^{73}$ These opportunities give space for representatives to raise locally informed issues with the international community which may influence the decision-making of the Secretariat and the Security Council when formulating the mission mandate.

An opportunity for the vital core to be identified at the national level was at the Bangui National Forum in May 2015. The Forum aimed to provide space for national reconciliation and allow for discussion on the peace process with a wide range of participants. ${ }^{74}$ Over 600 representatives attended representing the government, political parties, civil society, the media, and religious organisations. MINUSCA held a workshop to prepare for the Forum for national stakeholders and international partners and MINUSCA supported local consultations to collect the views of a wide range of people in advance of the forum, an effort welcomed by the Security Council. ${ }^{75}$ The support MINUSCA provided

\footnotetext{
${ }^{70} \mathrm{UN}, \mathrm{S} / 2014 / 142$ (2014), para 56.

71 ibid. para 58.

${ }^{72} \mathrm{UN}, \mathrm{S} / 2016 / 565$ (2016), para 4.

${ }^{73} \mathrm{UN}, \mathrm{S} / P V .7407$ (2015), 2 as per Mr. Delattre.

${ }^{74}$ Topics discussed were DDR, security sector reform, the reconstitution of FACA, the rule of law, and political and economic governance. UN, S/2014/857 (2014), para 19.

75 ibid. para 34; UN, S/PV.7329 (2014), 2 as per Mr. Ladsous; UN, S/PRST/2014/28 (2014), 1; UN, S/2015/227

(2015), para 30; UN, S/RES/2217 (2015), para 6.
} 
The Version of Record of this manuscript has been published and is available in International Peacekeeping http://www.tandfonline.com/10.1080/13533312.2020.1733423

to hold a large national forum on the peace process allowed for the Central African people to be directly included in national reconciliation and consequently, to be empowered. President Touadera reported to the Security Council that "the Bangui Forum accorded significant attention to the issue of victims, who were able to share their views and their expectations. ${ }^{~} 76$ However, Lombard and Picco have highlighted that the Forum had little mention of activities and initiatives at the local level and instead focused on national responses for achieving justice for victims such as the Special Criminal Court. ${ }^{77}$ Unfortunately, no follow-up national forums have been held to address the gap of discussing local issues which hampers the ability of people to be able to speak about concerns most relevant to them and their communities. Importantly, the $\mathrm{UN}$ has since recognised the importance of understanding local perceptions with the Secretary-General making specific recommendations that would aim to make sure the UN "take[s] into account the views and needs of Central Africans." 78

Recently in Bangui, tensions escalated in a predominantly Muslim neighbourhood, the PK5, and the community requested the government and MINUSCA to step in. ${ }^{79}$ MINUSCA and the CAR armed forces (FACA) arrested and disarmed criminal groups in the neighbourhood, seized weapons, ammunition, and narcotics. ${ }^{80}$ An operation such as this is a prime example of the UN forces responding to a direct security threat communicated from the local level. Community liaison assistants (CLAs) are also in use by MINUSCA to identify security threats. The assistants are 'critical links' between the mission and communities in remote areas ${ }^{81}$ CLAs are recruited to help the missions gain public support for the mandate, they speak the local language, can find out the risks to communities, act at mediators, and communicate outcomes to both civilian and military contingents of an operation. ${ }^{82}$ CLAs are able to work with communities to formulate protection strategies and alert mechanisms for community security. ${ }^{83}$ However, it should be noted that CLAs may lead to a particular community feeling underrepresented where the CLA is from a different ethnicity or where a community feels the CLA, as a local employee of the $\mathrm{UN}$, is using their $\mathrm{UN}$ role to spy on them. ${ }^{84}$ The direct involvement of MINUSCA with communities allows for the people affected to raise the issues most relevant to them which is necessary for the realisation of human security's principles. A bottom-up approach is important to make the peace process as locally owned as possible.

\footnotetext{
${ }^{76}$ UN, S/PV.7711 (2016), p.2 as per President Touadera.

${ }^{77}$ Lombard and Picco, "Distributive Justice at War," 15-16.

${ }^{78} \mathrm{UN}, \mathrm{S} / 2018 / 922$ (2018), para 56; UN, S/PV.8378 (2018), p.17 as per Mr. Allen.

${ }^{79} \mathrm{UN}, \mathrm{S} / 2018 / 611$ (2018), para 16.

80 ibid. para 17.

${ }^{81}$ UN, S/2015/732 (2015), para 33; UN, S/2018/611 (2018), para 40.

${ }^{82}$ Mahmoud, "People-Centred Approaches to Peace" 98.

${ }^{83} \mathrm{UN}, \mathrm{S} / 2016 / 305$ (2016), para 26.

${ }^{84}$ Mahmoud, "People-Centred Approaches to Peace" 96-7.
} 
The Version of Record of this manuscript has been published and is available in International Peacekeeping http://www.tandfonline.com/10.1080/13533312.2020.1733423

\subsection{Vulnerability}

The specifics of vulnerability are given little attention in the reports and meetings held on MINUSCA. The most notable identification of vulnerability is with regards to women and children. In Security Council meetings it is mentioned a number of times that women and children form the most vulnerable segments of the population and are 'particularly vulnerable' ${ }^{85}$ The reason for this is largely because of widespread sexual violence against women and the use of child soldiers by armed groups in the CAR. ${ }^{86}$ Attention being given to women and children in armed conflict is not uncommon with the Security Council establishing a Working Group on Children in Armed Conflict in 2005 and an Informal Expert Group on Women, Peace and Security in $2016 .{ }^{87}$

Despite mentioning the vulnerability of women and children in the CAR the Security Council does not discuss building resilience of those vulnerable groups in its meetings. It can be read into a number of MINUSCA's activities that the result would be improved resilience. For instance, MINUSCA, alongside the government and UNICEF, facilitated the holding of school exams in various prefectures and women have been involved in labour intensive work programmes as part of community violence reduction programmes.$^{88}$ In addition, women have routinely been empowered to participate in the peace process which consequently allows for the building of resilience. Nevertheless, an express concern for building the resilience of vulnerable groups is absent from the UN's reporting on MINUSCA.

Other groups have, on occasion, been identified by the Security Council or Secretariat as vulnerable. ${ }^{89}$ Namely, the elderly, disabled, and the Muslim community. The Secretary-General reported that the elderly is disproportionately affected by the violence in the CAR but no further details are given.${ }^{90}$ Likewise, in its first renewal of MINUSCA's mandate the Security Council expressed concern for the situation of persons with disabilities and the need to address their situation in the humanitarian response. ${ }^{91}$ The concern for the disabled was removed from later renewals of the mandate.

During the conflict the Muslim community has been targeted by the anti-Balaka in retaliation for the actions of the ex-Séléka. Consequently, a large part of the Muslim population has been displaced or has left the CAR. ${ }^{92}$ The UN refers to these communities as vulnerable on a couple of occasions. ${ }^{93}$

\footnotetext{
${ }^{85}$ UN, S/PV.8187 (2018), 11 Mr. Ndong Mba; UN, S/PV.8102 (2017), 2 as per Mr. Delattre; UN, S/PV.8084 (2017), 9 as per Mr. Inchauste Jordán.

${ }^{86}$ UN, $S / 2013 / 677$ (2013), para 10; UN, S/PV.7069 (2013), 2 as per the Deputy Secretary-General.

${ }^{87} \mathrm{UN}, \mathrm{S} / \mathrm{RES} / 1612$ (2005); UN, S/RES/2242 (2015).

${ }^{88}$ UN, S/2018/125 (2018), para 10; UN, S/2016/565 (2016), para 18; UN, S/2017/865 (2017), para 42.

${ }^{89}$ Vulnerable groups have also been mentioned by the Independent Expert on the situation of human rights in the Central African Republic with further mention of persons living in remote areas and internally displaced persons. UN, A/HRC/42/61 (2019), para 87.

${ }^{90} \mathrm{UN}, S / 2014 / 142$ (2014), para 14.

${ }^{91} \mathrm{UN}, \mathrm{S} / \mathrm{RES} / 2217$ (2015), 4.

${ }^{92} \mathrm{UN}, \mathrm{S} / 2014 / 562$ (2014), para 3.

${ }^{93} \mathrm{UN}, \mathrm{S} / 2015 / 85$ (2015), 2; UN, $S / 2015 / 576$ (2015), para 20.
} 
The Version of Record of this manuscript has been published and is available in International Peacekeeping http://www.tandfonline.com/10.1080/13533312.2020.1733423

However, the planning of the mission's PoC strategy did not identify Muslims, or Christians for that matter, as particularly vulnerable. ${ }^{94}$ It is likely that the UN has tried to avoid religious issues in its response to the CAR to ensure the organisation did not give credence to the claims that the conflict is a religious one. Instead the Under-Secretary-General for Peacekeeping Operations claims, "religion is not at the heart of the difficulties facing the Central African Republic." 95 It is difficult to assess whether express identification as vulnerable would improve the situation of displaced Muslim individuals but what is clear is that resilience needs to be built to prevent future displacements. The UN may have to recognise that it needs to specifically work with Muslim communities to ensure they are able to have a voice in the CAR and withstand future instability without the need to flee. The mission would fail, in part, if Muslim individuals were unable to return to their homes or in the future were forced to flee once again in the absence of UN forces.

\subsection{Protection}

MINUSCA was mandated from the start with a clear protection of civilians mandate. ${ }^{96}$ The mandate includes protecting the population from physical violence, through robust force, active patrolling, and the use of Children Protection Advisors and Women Protection Advisors. ${ }^{97}$ The purpose is to deter and restrict the activities of armed groups in cooperation with the French Operation Sangaris force. ${ }^{98}$ MINUSCA has been faced with a high level of violence throughout its deployment and in 2015 the protection of civilians "remained the highest priority task for MINUSCA." 99

The first key area for protection is the so-called 'robust' use of force. Since 2016 the mission has had a strategic objective to support the creation of conditions that will reduce the presence and threat of armed groups through a "proactive and robust posture without prejudice to the basic principles of peacekeeping." 100 The use of robust force is intended to provide for the restoration of state authorities and provision of basic services. ${ }^{101}$ Interestingly, the UN Independent Expert on the situation of human rights in the Central African Republic, Marie-Thérèse Keita Bocoum, called for a strategy on the 'neutralisation' of armed groups in the CAR. ${ }^{102}$ Thus far, the neutralisation of armed groups has not been included in MINUSCA's mandate to denote peace enforcement action similar to that taken by the Force Intervention Brigade deployed as part of the UN Stabilization Mission in the Democratic Republic of the Congo (MONUSCO).

\footnotetext{
${ }^{94} \mathrm{UN}, \mathrm{S} / 2014 / 562$ (2014), para 45.

${ }^{95} \mathrm{UN}, \mathrm{S} / \mathrm{PV} .7578$ (2015), 3 as per Mr. Ladsous.

96 UN, S/RES/2149 (2014), para 30(a).

97 ibid. para 30(a)(i), (ii).

${ }^{98} \mathrm{UN}, \mathrm{S} / 2015 / 576$ (2015), para 20.

99 ibid. para 29.

${ }^{100} \mathrm{UN}, \mathrm{S} /$ RES/2301 (2016), para 34; Restated in UN, S/RES/2387 (2017) para 39.

${ }^{101} \mathrm{UN}, \mathrm{S} / 2017 / 473$ (2017), para 2

102 UN, "UN expert calls for calm."
} 
The Version of Record of this manuscript has been published and is available in International Peacekeeping http://www.tandfonline.com/10.1080/13533312.2020.1733423

In February 2017 Operation Bekpa sought to stabilise the town of Bambari by securing the agreement that the armed groups would leave. MINUSCA used armed helicopters to engage armed groups attempting to re-enter the town. ${ }^{103}$ Lieutenant General Keïta reported to the Security Council that the "operation succeeded because we bent various administrative rules, challenged some limiting agreements with troops and changed morale where the use of force was involved." 104 The robust posture of MINUSCA forces is perceived to be preventative and avert 'major armed confrontations' and improve security. ${ }^{105}$ For instance, MINUSCA undertook robust operations to 'expel' the Front démocratique group from roads between Baboua and Beloko. ${ }^{106}$ More recently, the aforementioned 'joint disarmament and arrest operation' in Bangui's PK5 neighbourhood, launched alongside FACA resulted in armed raids which led to exchanges of fire and the death of a peacekeeper. ${ }^{107}$ An operation that includes armed raids to stop the activities of criminal gangs is an example of an action that supports the extension of state authority and toes the fine line between a 'robust posture' and taking the initiative in enforcement activity. ${ }^{108}$ In 2019 it was reported that violence between FACA and the Union pour la paix en Centrafrique 'prompted' MINUSCA to launch a robust operation to protect civilians that involved MINUSCA seizing and dismantling bases of the armed group. ${ }^{109}$

Under the analytical framework, protection means upholding rights and freedoms, taking preventive not reactive steps, and identifying gaps in protection. The UN consistently attempts to create a protective environment under its protection of civilian strategies where a robust posture is used to deter violence against civilians. To be in line with human security this must mean creating a protective environment which prevents violence against civilians and not one that necessitates UN intervention after the fact.

Recently, MINUSCA has been supporting the redeployment of FACA. Following the desertion of a large number of CAR troops the Transitional Authorities sought assistance with rebuilding its military capabilities. The EU deployed a training mission (EUTM RCA) in 2016 to assist with defence sector reform and has trained almost 3000 FACA soldiers who are now being redeployed to work alongside international forces. ${ }^{110}$ The UN stresses the members of FACA need "clean criminal and human rights records." 111 However, given the history of abuses by FACA it is paramount that communities trust the forces will not commit further human rights violations. ${ }^{112}$ MINUSCA has carried out joint patrols with FACA and supported their redeployment to Obo and Paoua on an ad hoc and

${ }^{103}$ UN, S/2017/473 (2017), para 11; UN, S/PV.7947 (2017), 12 as per Mr. Barro.

${ }^{104}$ UN, S/PV.7947 (2017), 8 as per Lieutenant General Keïta.

105 UN, S/2016/565 (2016), para 41; UN, S/2015/576 (2015), para 25.

${ }^{106} \mathrm{UN}, \mathrm{S} / 2015 / 576$ (2015), para 23.

${ }^{107}$ UN, S/2018/611 (2018), paras 16-7; UN, "Central African Forces and MINUSCA launch a disarmament and arrest operation"; UN, "MINUSCA condemns fresh attack against peacekeepers in Bangui."

108 See e.g. Gilder, "The Effect of 'Stabilization' in the Mandates and Practice of UN Peace Operations."

${ }^{109}$ UN, S/2019/147 (2019), para 21.

${ }^{110}$ EUTM, "European Union Training Mission in Central African Republic (EUTM- RCA)."

${ }^{111}$ UN, S/2018/463 (2018), para 22.

112 This issue is recognised by the UN here, $S / 2018 / 463$ (2018), paras 4, 25. 
The Version of Record of this manuscript has been published and is available in International Peacekeeping http://www.tandfonline.com/10.1080/13533312.2020.1733423

temporary basis. ${ }^{113}$ In the interim, while FACA regains the trust of the CAR people, the UN forces risk damaging their relationship with communities once the UN begins to cooperate more frequently with FACA forces. One way to mitigate the risk of marginalisation is by ensuring the mandate is clearly disseminated to the population and it is explained that, in the case of MINUSCA, the EU-trained FACA soldiers must comply with the HRDDP. Karlsrud says the emphasis on the HRDDP shows there are "lingering concerns" about close cooperation with other actors. ${ }^{114}$ The UN further needs to remain committed to the HRDDP to ensure the forces it works with under a stabilization mandate are not a risk to the reputation of the UN's blue helmets.

The second key area of protection that is important for human security is preventing sexual violence and abuse against women and children. ${ }^{15}$ For the first time UN-Women and UNDPKO provided specialized pre-deployment training to MINUSCA on preventing sexual violence. ${ }^{116}$ The statistics on sexual violence in the CAR are staggering with an estimated $44.5 \%$ of the population suffering from sexual and gender-based violence in 2014. ${ }^{117}$ To prepare for this reality MINUSCA ran around 70 training sessions on sexual violence, launched an evaluation of centres for victims of sexual violence, and supported the Government in developing a strategy for investigating sexual violence. ${ }^{118}$ MINUSCA's work on sexual violence, with the assistance of Women Protection Advisors, are directly tied to the rule of law efforts and ending impunity. MINUSCA has been seeking the prosecution of gender and sexual violence-based cases alongside both preventing future cases and giving support for victims. ${ }^{119}$

However, gender and sexual based violence cannot be discussed without acknowledging that MINUSCA and other international forces have been responsible for various instances of sexual abuse. At first the UN was slow to respond to the allegations against its peacekeepers leading to an External Independent Panel to review the allegations. ${ }^{120}$ The General Assembly adopted a resolution approving a zero-tolerance policy on sexual exploitation and abuse, but allegations continued against MINUSCA personnel with new reports of abuse throughout 2017. ${ }^{121}$ The MINUSCA mandate was renewed in 2017 to include stronger provisions for the prevention of sexual abuse. ${ }^{122}$ The Security Council stipulates that all personnel will be vetted for sexual misconduct and troop contributing countries should provide predeployment awareness training ensure 'full accountability' for their personnel. ${ }^{123}$

\footnotetext{
${ }^{113}$ UN, S/PV.7787 (2016), 2 as per Mr. Ladsous; UN, S/2018/463 (2018), para 5.

${ }^{114}$ Karlsrud, "From Liberal Peacebuilding to Stabilization and Counterterrorism," 9.

115 UN, S/RES/2149 (2014), paras 15, 30(a)(ii), 30(e)(ii).

${ }^{116}$ UN, $S / P V .7206$ (2014), 5 as per Ms. Mlambo-Ngcuka.

${ }^{117} \mathrm{UN}, \mathrm{S} / 2014 / 562$ (2014), para 17.

${ }^{118}$ UN, S/2014/562 (2014), para 48; UN, S/2014/857 (2014), para 45; UN, S/2015/227 (2015), para 45.

${ }^{119} \mathrm{UN}, \mathrm{S} / 2015 / 576(2015)$, para 52.

${ }^{120}$ ibid. para 91; UN, SC/12010-AFR/3198-PKO/514 (2015).

${ }^{121} \mathrm{UN}, A / R E S / 71 / 278$ (2017); UN, S/2017/473 (2017), para 69.

122 UN, S/RES/2387 (2017) para 52; UN, S/PV.8102 (2017), 4 as per Ms. Sison.

${ }^{123} \mathrm{UN}, \mathrm{S} / \mathrm{RES} / 2387$ (2017), para 52.
} 
The Version of Record of this manuscript has been published and is available in International Peacekeeping http://www.tandfonline.com/10.1080/13533312.2020.1733423

\subsection{Empowerment}

During the planning stages it was understood that the crisis affecting the country could not be resolved without dialogue between a broad spectrum of Central Africans. ${ }^{124}$ MINUSCA has attempted to facilitate this by empowering women to have an active role in an inclusive peace process. In its first mandate, MINUSCA was instructed to facilitate and provide technical assistance to the electoral process ensuring "full and effective participation of women at all levels and at an early stage". ${ }^{125}$ The mandates also recognise gender as a cross-cutting issue and that the mission will assist the government in making sure women are represented in all spheres and at all levels. ${ }^{126}$ The Executive Director of UNWomen reported to the Security Council that "[e]mpowered women are the best drivers of growth, the best hope of reconciliation and the best buffer against the radicalization of youth and the repetition of cycles of violence." ${ }^{27} \mathrm{UN}-$ Women assisted MINUSCA in promoting women's participation and leadership for local reconciliation, national dialogues, and transitional justice. ${ }^{128}$ Women's participation is key for demanding improvements in the system of protection which caters for women in particular and their specific vulnerabilities. Allowing space for women to use their voices will allow for better identification of how security issues are affecting communities and how the international community can respond.

MINUSCA has specifically advocated for women to play a bigger role in national politics. The mission pushed for a minimum of $30 \%$ representation of women in the national consultation process. ${ }^{129}$ There is not, however, a legal quota for female candidates in elections. ${ }^{130}$ The 2016 elections saw only one woman elected in the first round of voting and five in the second, out of 131 seats, representing just $4.5 \%$ of elected candidates. ${ }^{131}$ Furthermore, a large number of women voted but since the end of the transitional government, where there was a female head of state, there has been a "reassertion of the prevailing norms of gender inequality in society into the democratic process". ${ }^{132}$ Women in the CAR also have limited financial resources for political campaigns and a low literacy rate. ${ }^{133}$ The Security Council does continue to reiterate the need for the participation of women in the peace process and participation in inclusive dialogues for political agreement but more work is needed to ensure women are given the resources to have effective participation. ${ }^{134}$

\footnotetext{
${ }^{124}$ UN, S/2014/142 (2014), para 73; UN, S/PV.7153 (2015), 4 as per Mr. Kongo-Doudou.

125 UN, S/RES/2149 (2014), para 30(b)(v).

126 ibid. para 35.

${ }^{127}$ UN, S/PV.7206 (2014), 6 as per Ms. Mlambo-Ngcuka.

128 ibid. 4 as per Ms. Mlambo-Ngcuka.

${ }^{129}$ UN, S/2016/672 (2016), 2.

130 The UN successfully advocated for a quota in Mali where there must be a minimum of $30 \%$ of female candidates. UN. S/2016/819 (2016), para 11

${ }^{131} \mathrm{UN}, \mathrm{S} / 2016 / 305$ (2016), para 10.

132 UN, S/2016/672 (2016), 3.

133 ibid. 3.

${ }^{134}$ UN, S/PV.8291 (2018), 8 as per Mr. Delattre; UN, S/PRST/2018/14 (2018), 2.
} 
The Version of Record of this manuscript has been published and is available in International Peacekeeping http://www.tandfonline.com/10.1080/13533312.2020.1733423

Since 2016, MINUSCA has worked towards national reconciliation through "an inclusive process that involves men and women of all social, economic, political, religious and ethnic backgrounds, including, those displaced by the crisis". ${ }^{135}$ MINUSCA had previously, in 2015, established local peace and reconciliation committees in cooperation with UNDP but from 2017 the committees formed part of the President's peace infrastructure. ${ }^{136}$ The committees are elected by the communities and "are expected to solve local conflicts and promote peace through mediation and dialogue." ${ }^{137}$ Furthermore the committees "offer agency to women, members of civil society, religious leaders and young people." 138 This is remarkably similar to the human security aim of giving people the ability to act on their own behalf and on the behalf of others. ${ }^{139}$ Examples of local peace committee activities include community awareness campaigns, reopening of markets, and facilitating dialogue between farmers and herders to resolve differences without the influence of armed groups. ${ }^{140}$ In 2019 the Secretary-General reported that a local committee created following a peace agreement in Bangassou had been working on providing conditions for the safe return of Muslims who fled in $2017 .{ }^{141}$ By creating and supporting local peace and reconciliation committees the mission is preparing for when it will no longer be present and communities will need to resolve differences without conflict. Supporting the committees is an example of how MINUSCA aims to strengthen the capacity of individuals and communities to resolve conflicts. Having the capacity to mitigate the impact of insecurities and make better choices is a core aspect of empowerment that is being operationalised by MINUSCA.

\section{$4 \quad$ Peacebuilding at the local level and the threat posed by militarisation}

Two aspects of MINUSCA's stabilization mandate appear to be at loggerheads following the above study of the mission. On the one hand, the UN can be seen to pursue inclusive peace processes as part of their peacebuilding agenda with local engagement as a priority. There appears to be an implicit understanding in the mission that the peace process needs to involve some level of bottom-up empowerment to allow individuals to 'make better choices' and avoid conflict in the future. On the other hand, the mission is a highly militarised endeavour with a robust mandate which includes cooperation with FACA and the use of 'robust' force in pursuit of stability.

The UN has not always sought to involve the local in peacebuilding efforts. Instead there was previously an understanding that liberal peacebuilding from the top would trickle down to peace at the

\footnotetext{
${ }^{135} \mathrm{UN}, \mathrm{S} / \mathrm{RES} / 2301$ (2016), 1.

${ }^{136} \mathrm{UN}, \mathrm{S} / 2015 / 918$ (2015), para 15.

${ }^{137} \mathrm{UN}, \mathrm{S} / 2017 / 94$ (2017), para 21.

${ }^{138}$ UN, S/PV.8558 (2019), p.11 as per Mr. Allen.

${ }^{139}$ Commission on Human Security, Human Security Now, 11.

${ }^{140} \mathrm{UN}, S / 2017 / 473$ (2017), para 21.

${ }^{141}$ UN, S/2019/147 (2019), para 12.
} 
The Version of Record of this manuscript has been published and is available in International Peacekeeping http://www.tandfonline.com/10.1080/13533312.2020.1733423

local level. For instance, in the DRC in the early to mid-2000s peacebuilding was focused on the peace process and elections at the national level. ${ }^{142}$ However, top-down approaches have been described as "inherently hegemonic and out-of-touch with local realities" and studies have shown that success at the national level does not necessarily mean there will be equal success at the local level. ${ }^{143}$ Instead, topdown approaches can miss the nuances of a conflict, worsen conditions, and marginalise communities. ${ }^{144}$ To avoid this the UN needs to navigate a complex environment ensuring both engagement at the local level and wider national reconciliation. This view is reflected by UN policy which understands that to achieve effective peacebuilding there must be local ownership and the incorporation of local partners into the process. ${ }^{145}$ Peacebuilding as a whole is intrinsically linked to improving human security. For instance, Hanlon and Christie have suggested that without peacebuilding efforts to re-establish the police, judicial system and a functioning bureaucracy individuals "struggle to regain their security." 146

A recent study of the other two ongoing stabilization missions, United Nations Multidimensional Integrated Stabilization Mission in Mali (MINUSMA) and MONUSCO, has concluded that stabilization mandates are "antithetical" to the UN's understanding of peacebuilding and strategies to engage the local are undermined by "an overarching militarized and state-centric blueprint for stabilization." 147 In a similar vein, the below discussion explains how MINUSCA has a focus on two aspects of human security as part of the peacebuilding agenda, namely entrenching the rule of law and empowerment of the local, but that militarisation risks undermining these efforts.

As part of its peacebuilding agenda, the UN has adopted a focus on the rule of law with the Secretary-General stating it is "at the very heart of the [UN's] mission". ${ }^{148}$ MINUSCA is an exemplary example of this with an unequivocal focus on ending impunity and rebuilding the rule of law. As explained above, the concept of human security has argued that protection from insecurity goes beyond physical protection and instead human security involves wider objectives. Insecurity can be caused by crime, insecurities involving employment, vulnerability, health and illness, and more. Sannerholm argues the rule of law is seen as a remedy for wider concerns of insecurity, such as social vulnerabilities, health or economic threats, as law governs many aspects of an individual's life from criminal justice to private economic affairs. ${ }^{149}$ Other reasons for the UN's focus on the rule of law have been given such

\footnotetext{
142 Autesserre, The Trouble with the Congo.

${ }^{143}$ Randazzo, "The paradoxes of the "everyday," 1353; Autesserre, "International Peacebuilding and Local Success," 118.

144 ibid. 1352.

${ }^{145}$ Curran and Hunt, "Stabilization at the Expense of Peacebuilding," 7. For an overview of local involvement with peacekeeping see von Billerbeck, Whose Peace?

${ }^{146}$ Hanlon and Christie, Freedom from Fear, Freedom from Want, 105.

${ }^{147}$ Curran and Hunt, "Stabilization at the Expense of Peacebuilding," 14.

${ }^{148}$ UN, S/2004/616 (2004), para 6.

149 Sannerholm, "Beyond the Rule of Law Template," 68.
} 
The Version of Record of this manuscript has been published and is available in International Peacekeeping http://www.tandfonline.com/10.1080/13533312.2020.1733423

as addressing past wrongs and atrocities by providing the host state with a functioning judicial system and also the fact the rule of law assists with long-term peacebuilding. ${ }^{150}$

By focusing on the rule of law, MINUSCA put's into action the normative foundations of human security providing the framework for other, more ambitious goals. If this strategy is effective and holds legitimacy amongst local people the use of similar hybrid solutions, like the Special Criminal Court, could be deemed a suitable method of achieving rule of law goals in future mandates. Within the CAR, one study has indicated that individuals do believe those responsible for the conflict and crimes committed thereafter, should be punished. ${ }^{151}$ Whereas persons who have merely capitalised on the conflict and committed 'petty' crimes such as looting are much more varied ${ }^{152}$ Ending impunity though is difficult where there is little trust in the justice system with people believing trials are "won by the disputant who pays the magistrate more or by the one who has a better relationship with him". ${ }^{153}$ In the same study, interviewees indicated an international body would be needed to provide justice. ${ }^{154}$

Providing support and methods of ending impunity is a way in which the UN Security Council can link the mission's peacebuilding activities to wider agendas on international criminal justice and universal human rights. A focus on the rule of law and ending impunity could be a positive step for UN peace operations where missions can tap into the UN's rich expertise in the area. However, if the UN wishes to continue this strategy the Security Council will need to pay close attention to the outcome of the approach taken in the CAR. Local perceptions of justice and ending impunity are vital in shaping future approaches that provide visible justice that is trusted by local people. Particularly where host state forces are responsible for human rights violations the effectiveness of the UN's efforts in entrenching the rule of law become questionable. The UN must be resolute when it seeks to ensure the rule of law applies to all actors involved in a (post)conflict situation. Ending impunity cannot only be applied to some of those actors and importantly for a hybrid court heavily supported by the international community it cannot be seen to provide only victor's justice, especially where the UN have designated the state as the legitimate authority. The UN will need to balance its express support for building the capacity of the host state alongside its work on the rule of law and human rights to ensure the two areas are not in conflict and do not prevent the organisation from pursuing human security.

Empowerment, was visible in a range of MINUSCA's activities. Women in particular are a focus of UN peacebuilding activities with the Secretary-General specifically recognising that the participation of women is directly linked to the success of a peace process. ${ }^{155}$ To protect progress made on bottom-up empowerment, the UN needs to be forceful in its push for bottom-up inclusion in national

\footnotetext{
150 Tolbert and Solomon, "United Nations Reform and Supporting the Rule of Law in Post-Conflict Societies," 33; UN. A/59/565 (2004), para 229.

151 Picco, "I Am 100\% Central African," 36.

152 ibid. 36.

${ }^{153}$ Lombard and Picco, "Distributive Justice at War," 16.

154 ibid. 17.

${ }^{155}$ UN, S/2016/1137 (2016), para 69.
} 
The Version of Record of this manuscript has been published and is available in International Peacekeeping http://www.tandfonline.com/10.1080/13533312.2020.1733423

peace processes to ensure the organisation's positive work at the local level does in fact feed up to peace at the national level. MINUSCA's mandate makes frequent mention of promoting participation of a range of local-level actors and the mission assisted with the holding of the Bangui Forum. Progress though could be lost where resulting peace negotiations or government reconciliation plans do not adequately include local actors. For instance, the Bangui Form led to recommendations that there existed a need for the increased participation of citizens and the bridging of the gap between Bangui and the rest of the CAR. ${ }^{156}$ Bottom-up empowerment then would be an ideal method of achieving this aspiration. However, progress has been hindered by the government's failure to disseminate the outcomes of the Forum and MINUSCA's inability to influence the host state in its national level negotiations because of the mission's 'hands-off' approach. ${ }^{157}$

To realise the empowerment of the local the host state needs to feed local participation into the wider national reconciliation programmes. No matter how much the UN chooses to focus on empowerment little can be done without the host state's support for a bottom-up peace process. Similarly, within the UN the empowerment aspects of the mission must feed up into the decisionmaking of the Secretariat and Security Council. The mission documents examined above rarely identify where a decision has been taken due to local input being acted on by the Security Council. Quick impact projects (QIPs) for instance are mentioned as a method of reducing impoverishment, which "is helping to fuel armed groups." ${ }^{158}$ It is nevertheless unclear to what extent local input, where empowered persons identify the vital core, is utilised in determining what QIPs the mission will implement. For example, the UN reporting does not elaborate on whether local people in the fourth district of Bangui requested the mission to construct a sports and cultural centre for the youth, which forms one such QIP. ${ }^{159}$ Going forward, the UN's empowerment strategy will need more transparent reporting and would benefit from an overarching policy to guide the implementation of a mandate which calls for meaningful engagement with local populations. The Security Council in particular will need to provide space for local views to be listened to and acted upon for the UN to assist with building a truly bottom-up peace.

Militarisation within UN stabilisation missions is a trend which many texts have discussed and undoubtedly will expand on in the future. For the purposes of this article it will be outlined how militarisation can undermine the UN's human security-related efforts but that is not to say it is the only negative associated with militarisation or indeed that there are no positives. ${ }^{160}$ What is clear in MINUSCA is a preoccupation with robust responses to provide physical protection. MINUSCA has not primarily concerned itself with broader facets of human security-based protections such as environmental degradation, health threats or economic harm etc. In trying to achieve an absence of

\footnotetext{
156 Zahar and Mechoulan, "Peace by pieces?" 3.

157 ibid. 30, 36.

${ }^{158} \mathrm{UN}, S / P V .8084$ (2017), 6 as per Mr. Nébié.

${ }^{159} \mathrm{UN}, \mathrm{S} / 2014 / 857$ (2014), para 37.

${ }^{160}$ For other works which address the rising militarisation seen in UN peace operations please see, Karlsrud, The UN at War; de Coning, "Is stabilization the new normal?"
} 
The Version of Record of this manuscript has been published and is available in International Peacekeeping http://www.tandfonline.com/10.1080/13533312.2020.1733423

physical harm the UN has adopted a highly militarised and robust stance. Pugh has noted how a robust posture can lead to a preoccupation with force protection and a fortress culture surrounding UN bases as has been seen in the UN Mission in South Sudan (UNMISS). ${ }^{161}$ MINUSCA though is different. When MINUSCA deployed the host state had little control beyond Bangui and a robust, highly militarised posture was needed to deflect armed groups as the host state, with the support of the mission, extended state authority beyond the capital.

It is true that this drive toward greater militarisation is in part at the request of African states. Officials from African states have suggested militarisation is a precondition to being able to provide adequate protection during current conflicts. ${ }^{162}$ To demonstrate the current African appetite for peacekeeping, at the beginning of the 2000s African countries provided 27\% of peacekeeping troops but today that number stands at $49 \%$ globally and $58 \%$ of the UN troops operating in Africa. ${ }^{163}$ Bode and Kalsrud have argued that greater African participation has meant a greater willingness to use force. ${ }^{164}$ Increasingly, major TCCs to missions are neighbouring states, regional partners or African Union members who will have a number of vested interests in quelling a conflict swiftly. Reasons such as curtailing refugees in the region or preventing the disruption to trade give nearby states, rightly or wrongly, reason to militarily involve themselves through a UN mission.

A key risk of increased militarisation is if missions such as MINUSCA proactively use force they risk intensifying violence and becoming a party to the conflict under international humanitarian law. ${ }^{165}$ The UN traditionally remains impartial and does not take sides in a conflict. However, with MINUSCA providing support to FACA and conducting joint operations there is the risk that the peacekeepers could lose their protections and be deemed combatants where increasing levels of force are used against armed groups. ${ }^{166}$ Another consequence of this is the potential for civilians to be harmed by an intensified conflict. If the UN engage armed groups on a more frequent basis there is the possibility of civilians being harmed as collateral damage. The use of robust force would then be counterproductive and undermine one of the core tenets of peacekeeping, the protection of civilians. The UN must balance the need to adopt a robust posture when countering well-armed, organised groups that pose a serious threat with the intensification of the conflict in mind.

On the point of impartiality, Laurence states, "UN peacekeepers can take forceful action and still be 'impartial' as long as they are advancing ostensibly universal goals, like promoting human rights." 167 This may be the case where the UN is using force against spoilers in the protection of civilians. However, where the UN is seen to be training and operating alongside host state forces

\footnotetext{
${ }^{161}$ Pugh, "Reflections on Aggressive Peace," 414.

162 Gelot, "Civilian protection in Africa," 166

${ }^{163}$ Bode and Karlsrud, "The use of force to protect civilians in United Nations peacekeeping," 465.

164 ibid. 465; See also, Riis Andersen, "The HIPPO in the room," 353.

165 Gilder, "The Effect of 'Stabilization' in the Mandates and Practice of UN Peace Operations."; Sloan, "UN peacekeeping and international law," 276; Maganza, "From Peacekeepers to Parties to the Conflict."

166 An interesting discussion on this point can be found here, Mathias, "UN Peacekeeping Today."

${ }^{167}$ Laurence, “An 'Impartial' Force?” 264.
} 
The Version of Record of this manuscript has been published and is available in International Peacekeeping http://www.tandfonline.com/10.1080/13533312.2020.1733423

impartiality becomes a thinly veiled perception. Longobardo has similarly argued robust missions are not impartial due to their active role in fighting armed groups. ${ }^{168}$ There is a delicate balance to be struck between militarisation alongside the host state on the one hand and inclusive peacebuilding processes on the other. The UN risks undermining its bottom-up empowerment work with communities to identify the vital core and security needs where militarisation leads to robust force being used in a partial manner. MINUSCA is mandated to support national reconciliation but where the mission is seen to be fighting an enemy alongside FACA there may be ethnic, religious, or other divisions, between communities that lead to the UN no longer being a trusted, impartial partner. Similarly, where conflict is intensified there is a risk that benefits of existing peacebuilding work may be lost.

To conclude this discussion on a slightly positive note, the UN's militarised protection strategy is framed by the organisation as preventative and preventative protection is the emphasis of human security. For instance, proactive patrolling conducted by MINUSCA is seen to be preventative to demonstrate to armed groups that the peacekeepers can and will deter violence. On a deeper level, with regards to sexual violence the UN has trained both its own and host state personnel in how to prevent sexual violence, and developed national policies with the government on preventative measures. However, a robust protection strategy is flawed in the sense that it addresses a narrow, militaristic notion of security. Robust patrols of heavily armed forces working in concert with newly-trained host state forces will be able to prevent some instances of sexual violence and deter armed groups but they cannot, on their own, take preventative action on other security concerns beyond physical protection.

\section{$5 \quad$ Conclusion}

By applying an analytical framework of human security this study has shown that MINUSCA has a clear focus on extending the authority of the state beyond Bangui, in particular with regard to the extension of the rule of law and rebuilding the justice system. MINUSCA has also supported a number of community-based initiatives both for consultation purposes and for empowering local communities to resolve their own security issues. The UN, on some occasions, facilitates dialogue with civil society and local communities, but it is unclear to what extent the dialogue influences mission choices when approving projects and, at a higher level, the mission priorities as defined by the Security Council. MINUSCA has become known for its use of robust force and has recently begun cooperating with FACA, which could have serious consequences. The fact this study has relied solely upon UN documentation, mainly Secretary-General reports and Security Council meeting records, leaves open questions about whether there is any disparity between what is reported and what is occurring in the field. Particularly in relation to how field activities are fed up into the reports and framed by UN

${ }^{168}$ Longobardo, "Robust Peacekeeping Mandates," 8, 15. 
The Version of Record of this manuscript has been published and is available in International Peacekeeping http://www.tandfonline.com/10.1080/13533312.2020.1733423

officials. Future research could delve into this further and seek to uncover whether the way mission activities are framed is in fact a true representation of the work at mission-level.

Nevertheless, the reporting shows that competing interests in the mission mandate risk undermining each other where militarisation and cooperating with the host state forces have adverse effects on the UN's ability to build peace at the local level, empower communities, and support national reconciliation. The UN will need to carefully consider how it wishes to proceed in future stabilization mandates to avoid a situation where engaging in war-fighting against spoilers or working closely alongside the state frustrates efforts to build an inclusive peace and build the capacity of communities. More work is needed to investigate the effects of each aspect of stabilization mandates. To name just one example, where force is used to displace armed groups there may be a risk of marginalisation in communities because of cooperation with host state forces which in turn undermines other peacebuilding activities. Lastly, the application of a human security lens is useful as a cognitive exercise to draw out aspects of the UN's approach which are not conducive to the input of individuals affected by a peace operation. The analytical framework could be used in other areas of research to assess whether the UN system has meaningful engagement with individuals.

\section{Acknowledgements}

I am grateful for feedback from both my PhD supervisors, Dr Ioannis Kalpouzos and Dr Mauro Barelli, on earlier versions of this work. I also received helpful comments from participants at both the 8th Annual Istanbul Human Security Conference (17-19 October 2018, Kadir Has Üniversitesi) and the 44th BISA Annual Conference 2019 (12-14 June 2019). I am indebted to the two anonymous reviewers for their detailed and thoughtful reviews. All errors are my own.

\section{Notes on contributor}

Alexander Gilder is a Lecturer in Law at Royal Holloway, University of London. His research currently follows two strands. First, Alex investigates themes related to stabilization in UN peacekeeping including robust force, counter-terrorism, and the effect of militarisation on other mandated tasks, such as entrenching the rule of law. Second, he is interested in the theory and history of international law. Alex has worked on the relationships between the concept of human security, the individual, and international law.

\section{ORCID}

Alexander Gilder https://orcid.org/0000-0002-8861-1433

\section{Bibliography}


The Version of Record of this manuscript has been published and is available in International Peacekeeping http://www.tandfonline.com/10.1080/13533312.2020.1733423

Acharya, Amitav. "Human Security" In The Globalisation of World Politics, eds John Baylis, Steve Smith and Patricia Owens. Oxford: Oxford University Press, $6^{\text {th }}$ ed, 2014.

Alkire, Sabina. “A Conceptual Framework for Human Security.” CRISE, Working Paper \#2, 2003. http://www3.qeh.ox.ac.uk/pdf/crisewps/workingpaper2.pdf.

Alkire, Sabina. "A Vital Core that Must Be Treated with the Same Gravitas as Traditional Security Threats." Security Dialogue 35(3) (2004): 359-60.

Autesserre, Séverine. "International Peacebuilding and Local Success: Assumptions and Effectiveness." International Studies Review 19 (2017): 114-132.

Autesserre, Séverine. The Trouble with the Congo: Local Violence and the Failure of International Peacebuilding. Cambridge: Cambridge University Press, 2010.

Bode, Ingvild, Karlsrud, John. "Implementation in practice: The use of force to protect civilians in United Nations peacekeeping." European Journal of International Relations 25(2) (2019): 458-485.

Chappuis, Fairlie. "Human Security and Security Sector Reform" In Mainstreaming Human Security in Peace Operations and Crisis Management, eds Benedek, Wolfgang, Kettemann, Matthias, Möstl, Markus. London: Routledge, 2011.

Chinkin, Christine and Mary Kaldor. International Law and New Wars. Oxford: Oxford University Press, 2017.

Commission on Human Security, Human Security Now. New York, 2003.

Curran, David and Hunt, Charles T. "Stabilization at the Expense of Peacebuilding in UN Peacekeeping Operations: More Than Just a Phase?" Global Governance (2020): 1-23.

Daft, Shireen. The Relationship Between Human Security Discourse and International Law: A Principled Approach. London: Routledge, 2017.

de Coning, Cedric, Chiyuki Aoi and John Karlsrud. "Towards a United Nations stabilization doctrine stabilization as an emerging UN practice" In UN Peacekeeping Doctrine in a New Era, eds Cedric de Coning, Chiyuki Aoi and John Karlsrud. London: Routledge, 2017.

de Coning, Cedric. "Is stabilization the new normal? Implications of stabilization mandates for the use of force in UN peacekeeping operations" In The Use of Force in UN Peacekeeping, ed Peter Nadin. London: Routledge, 2018.

EUTM. "European Union Training Mission in Central African Republic (EUTM- RCA).” 13 August 2018. https://eeas.europa.eu/sites/eeas/files/180823 mission_factsheet_eutm rca jul18 v1.pdf

Farer, Tom. "Human Security: Defining the Elephant and Imagining Its Tasks." Asian Journal of International Law 1(1) (2011): 43-55.

Fineman, Martha. "Vulnerability, Resilience, and LGBT Youth" Temple Political \& Civil Rights Law Review 23(2) (2014): 307-330.

Fortier, Patricia. "The Evolution of Peacekeeping” In Human Security and the New Diplomacy, eds Rob McRae, Don Hubert. Montreal: McGill-Queen's University Press, 2001.

Gelot, Linnéa. "Civilian protection in Africa: How the protection of civilians is being militarized by African policymakers and diplomats." Contemporary Security Policy 38(1) (2017): 161-173.

Gilder, Alexander. "The Effect of 'Stabilization' in the Mandates and Practice of UN Peace Operations." Netherlands International Law Review 66(1) (2019): 1-27.

Golberg, Elissa, Hubert, Don. "The Security Council and the Protection of Civilians" In Human Security and the New Diplomacy, eds Rob McRae, Don Hubert. Montreal: McGill-Queen's University Press, 2001.

Gorur, Aditi. "Defining the Boundaries of UN Stabilization Missions." Stimson, December 2016.

Hanlon R and Christie K, Freedom from Fear, Freedom from Want: An Introduction to Human Security. Toronto: University of Toronto Press, 2016.

Heathcote, Gina. "Women and children and elephants as justification for force." Journal on the Use of Force and International Law 4(1) (2017): 66-85.

High-Level Independent Panel on UN Peace Operations. Uniting Our Strengths for Peace: Politics, Partnership and People. New York: United Nations, 2015.

Human Rights Watch, "Central African Republic: Parliament Adopts Special Criminal Court Rule." 4 June 2018. https://www.hrw.org/news/2018/06/04/central-african-republic-parliament-adopts-special-criminalcourt-rules

Karlsrud, John. "From Liberal Peacebuilding to Stabilization and Counterterrorism." International Peacekeeping 26(1) (2019): 1-21,

Karlsrud, John. The UN at War: Peace Operations in a New Era. London: Palgrave Macmillan, 2018.

Kjeksrud, Stian, and Lotte Vermeij. "Protecting governments from insurgencies: The Democratic Republic of the Congo and Mali" In UN Peacekeeping Doctrine in a New Era, eds Cedric de Coning, Chiyuki Aoi and John Karlsrud. London: Routledge, 2017.

Laurence, Marion. "An 'Impartial' Force? Normative Ambiguity and Practice Change in UN Peace Operations." International Peacekeeping 26(3) (2019): 256-280 
The Version of Record of this manuscript has been published and is available in International Peacekeeping http://www.tandfonline.com/10.1080/13533312.2020.1733423

Lombard, Louisa, and Picco, Enrica. "Distributive Justice at War: Displacement and Its Afterlives in the Central African Republic." Journal of Refugee Studies (2019): 1-24.

Longobardo, Marco. "Robust Peacekeeping Mandates: An Assessment in Light of Jus Post Bellum." In The Justice of Peace and Jus Post Bellum, eds Stahn, Carsten, Iverson, Jens, Easterday, Jennifer. Oxford: Oxford University Press, 2020. (forthcoming - author preprint used).

Mac Ginty, Roger. “Against Stabilization.” Stability: International Journal of Security \& Development 1(1) (2012): 20-30.

Maganza, Bianca. "From Peacekeepers to Parties to the Conflict: An IHL's Appraisal of the Role of UN

Peace Operations in NIACs.” Journal of Conflict and Security Law (2020): 1-28. https://doi.org/10.1093/jcsl/krz032.

Mahmoud, Youssef. "People-Centred Approaches to Peace: At Cross Roads Between Geopolitics, Norms, and Practice." In United Nations Peace Operations in a Changing Global Order, eds Cedric de Coning, Mateja Peter. London: Palgrave Macmillan, 2019.

Mathias, Stephen. "UN Peacekeeping Today: Legal Challenges and Uncertainties." Melbourne Journal of International Law 18(2) (2017): 138-153.

Ogata, Sadako. "From State Security to Human Security." Ogden Lecture, Brown University, 26 May 2002 (on file with the author).

Ogata, Sadako. “The Human Security Commission's strategy.” Peace Review 16(1) (2004): 25-28.

Paris, Roland. "Human Security: Paradigm Shift or Hot Air?" International Security 26(2) (2001): 87-102.

Picco, Enrica. “"'I Am 100\% Central African” Identity and Inclusion in the Experience of Central African Muslim Refugees in Chad and Cameroon.” International Center for Transitional Justice. 14 March 2018. https://www.ictj.org/sites/default/files/ICTJ_CAR_report_100_percent_Central_African.pdf

Pugh, Michael. "Reflections on Aggressive Peace" International Peacekeeping 19(4) (2012): 410-425.

Randazzo, Elisa. "The paradoxes of the 'everyday': scrutinising the local turn in peace building." Third World Quarterly 37(8) (2016): 1351-1370.

Riis Andersen, Louise. "The HIPPO in the room: the pragmatic push-back from the UN peace bureaucracy against the militarization of UN peacekeeping." Internatioanal Affairs 94(2) (2018): 343-361.

Sannerholm, Richard, "Legal, Judicial and Administrative Reforms in Post-Conflict Societies: Beyond the Rule of Law Template." Journal of Conflict \& Security Law 12(1) (2007): 65-94.

Sloan, James. "UN peacekeeping and international law." In The Use of Force in UN Peacekeeping, ed Peter Nadin. London: Routledge, 2018.

Thérien, Jean-Philippe. "Human Security: The Making of a UN Ideology" Global Society 26(2) (2012): 191213.

Tobin, John. "Understanding Children's Rights: A Vision beyond Vulnerability." Nordic Journal of International Law 84(2) (2015): 155-182.

Tolbert, David, Solomon, Andrew. "United Nations Reform and Supporting the Rule of Law in Post-Conflict Societies." Harvard Human Rights Journal 19 (2006): 29-62.

Tull, Dennis. "The Limits and Unintended Consequences of UN Peace Enforcement: The Force Intervention Brigade in the DR Congo." International Peacekeeping 25(2) (2018): 167-190

UN. “(5a) Fatalities by Year, Mission and Incident Type.” UN Peacekeeping, 5 November 2018. https://peacekeeping.un.org/sites/default/files/statsbyyearmissionincidenttype_5a_15.pdf

UN. "Central African Forces and MINUSCA launch a disarmament and arrest operation against armed criminals in Bangui’s PK5 neighborhood.” MINUSCA, 8 April 2018.

https://minusca.unmissions.org/en/central-african-forces-and-minusca-launch-disarmament-and-arrestoperation-against-armed-criminals

UN. "MINUSCA condemns fresh attack against peacekeepers in Bangui." MINUSCA, 10 April 2018. https://minusca.unmissions.org/en/minusca-condemns-fresh-attack-against-peacekeepers-bangui

UN. "UN expert calls for calm, protection of civilians in Central African Republic.” MINUSCA, 3 May 2018. https://minusca.unmissions.org/en/un-expert-calls-calm-protection-civilians-central-african-republic

UN. A/3943. Summary of the experiences derived from the establishment and operation of the force. New York: United Nations, 9 October 1958.

UN. A/46/185. Model agreement between the United Nations and Member States contributing personnel and equipment to United Nations peacekeeping operations. New York: United Nations, 13 May 1991.

UN. A/59/565. High Level Panel on Threats, Challenges and Change. New York: United Nations, 2 December 2004.

UN. A/68/19. Report of the Special Committee on Peacekeeping Operations. New York: United Nations, 24 February - 21 March 2014.

UN. A/HRC/42/61. Human rights situation in the Central African Republic. New York: United Nations, 9 August 2019. 
The Version of Record of this manuscript has been published and is available in International Peacekeeping http://www.tandfonline.com/10.1080/13533312.2020.1733423

UN. A/RES/66/290. Follow-up to paragraph 143 on human security of the 2005 World Summit Outcome. New York: United Nations, 25 October 2012.

UN. A/RES/71/278. Resolution 71/278. New York: United Nations, 20 March 2017.

UN. S/2004/616. The Rule of Law and Transitional Justice in Conflict and Post-Conflict Societies. New York: United Nations, 23 August 2004.

UN. S/2013/677. Report of the Secretary-General on the Central African Republic submitted pursuant to paragraph 22 of Security Council resolution 2121 (2013). New York: United Nations, 15 November 2013.

UN. S/2014/142. Report of the Secretary-General on the Central African Republic submitted pursuant to paragraph 48 of Security Council resolution 2127 (2013). New York: United Nations, 3 March 2014.

UN. S/2014/562. Report of the Secretary-General on the situation in the Central African Republic. New York: United Nations, 1 August 2014.

UN. S/2014/857. Report of the Secretary-General on the situation in the Central African Republic. New York: United Nations, 28 November 2014.

UN. S/2014/928. Letter dated 19 December 2014 from the Secretary-General addressed to the President of the Security Council. New York: United Nations, 22 December 2014.

UN. S/2015/227. Report of the Secretary-General on the situation in the Central African Republic. New York: United Nations, 1 April 2015.

UN. S/2015/576. Report of the Secretary-General on the situation in the Central African Republic. New York: United Nations, 29 July 2015.

UN. S/2015/732. Report of the Secretary-General on the situation in Mali. New York: United Nations, 22 September 2015.

UN. S/2015/85. Letter dated 29 January 2015 from the Secretary-General addressed to the President of the Security Council. New York: United Nations, 29 January 2015.

UN. S/2015/918. Report of the Secretary-General on the situation in the Central African Republic. New York: United Nations, 30 November 2015.

UN. S/2016/305. Report of the Secretary-General on the situation in the Central African Republic. New York: United Nations, 1 April 2016.

UN. S/2016/565. Special Report of the Secretary-General on the strategic review of the United Nations Multidimensional Integrated Stabilization Mission in the Central African Republic. New York: United Nations, 22 June 2016.

UN. S/2016/672. Letter dated 29 July 2016 from the Permanent Representatives of Spain and the United Kingdom of Great Britain and Northern Ireland to the United Nations addressed to the Secretary-General. New York: United Nations, 2 August 2016.

UN. S/2016/819. Report of the Secretary-General on the situation in Mali. New York: United Nations, 29 September 2016.

UN. S/2016/1137. Report of the Secretary-General on the situation in Mali. New York: United Nations, 30 December 2016.

UN. S/2017/473. Report of the Secretary-General on the Central African Republic. New York: United Nations, 2 June 2017.

UN. S/2017/865. Report of the Secretary-General on the situation in the Central African Republic. New York: United Nations, 18 October 2017.

UN. S/2017/94. Report of the Secretary-General on the situation in the Central African Republic. New York: United Nations, 1 February 2017.

UN. S/2018/125. Report of the Secretary-General on the situation in the Central African Republic. New York: United Nations, 15 February 2018.

UN. S/2018/463. Letter dated 15 May 2018 from the Secretary-General addressed to the President of the Security Council. New York: United Nations, 16 May 2018.

UN. S/2018/611. Situation in the Central African Republic Report of the Secretary-General. New York: United Nations, 18 June 2018.

UN. S/2018/922. Report of the Secretary-General on the Central African Republic, 15 June-15 October 2018. New York: United Nations, 15 October 2018.

UN. S/2019/147. Central African Republic. New York: United Nations, 15 February 2019.

UN. S/2019/498. Central African Republic. New York: United Nations, 17 June 2019.

UN. S/2019/822. Central African Republic. New York: United Nations, 15 October 2019.

UN. S/PRST/2014/28. Statement by the President of the Security Council. New York: United Nations, 18 December 2014.

UN. S/PRST/2018/14. Statement by the President of the Security Council. New York: United Nations, 13 July 2018.

UN. S/PV.7069. 7069 th Meeting. New York: United Nations, 25 November 2013.

UN. S/PV.7153. 7153 ${ }^{\text {rd }}$ Meeting. New York: United Nations, 10 April 2014. 
The Version of Record of this manuscript has been published and is available in International Peacekeeping http://www.tandfonline.com/10.1080/13533312.2020.1733423

UN. S/PV.7206. 7206 ${ }^{\text {th }}$ Meeting. New York: United Nations, 24 June 2014.

UN. S/PV.7246. 7246 th Meeting. New York: United Nations, 19 August 2014.

UN. S/PV.7329. 7329th Meeting. New York: United Nations, 9 December 2014.

UN. S/PV.7407. 7407th Meeting. New York: United Nations, 18 March 2015.

UN. S/PV.7578. 7578 th Meeting. New York: United Nations, 14 December 2015.

UN. S/PV.7711. 7711 $1^{\text {st }}$ Meeting. New York: United Nations, 10 June 2016.

UN. S/PV.7734. 7734 th Meeting. New York: United Nations, 8 July 2016.

UN. S/PV.7787. 7787th Meeting. New York: United Nations, 10 October 2016.

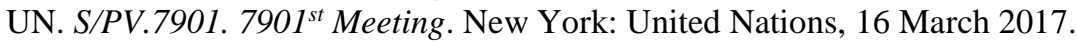

UN. S/PV.7947. 7947th Meeting. New York: United Nations, 23 May 2017.

UN. S/PV.8084. 8084th Meeting. New York: United Nations, 6 November 2017.

UN. S/PV.8102. 8102 ${ }^{\text {nd }}$ Meeting. New York: United Nations, 15 November 2017.

UN. S/PV.8187. 8187 heeting. New York: United Nations, 22 February 2018.

UN. S/PV.8291. 8291 ${ }^{\text {st }}$ Meeting. New York: United Nations, 21 June 2018.

UN. S/PV.8378. 8378 $8^{\text {th }}$ Meeting. New York. United Nations, 23 October 2018.

UN. S/PV.8558. 8558 ${ }^{\text {th }}$ Meeting. New York. United Nations, 20 June 2019.

UN. S/RES/1612. Resolution 1612. New York: United Nations, 16 July 2005.

UN. S/RES/2149. Resolution 2149. New York: United Nations, 10 April 2014.

UN. S/RES/2212. Resolution 2212. New York: United Nations, 26 March 2015.

UN. S/RES/2217. Resolution 2217. New York: United Nations, 28 April 2015.

UN. S/RES/2242. Resolution 2242. New York: United Nations, 13 October 2015.

UN. S/RES/2301. Resolution 2301. New York: United Nations, 26 July 2016.

UN. S/RES/2387. Resolution 2387. New York: United Nations, 15 November 2017.

UN. S/RES/2448. Resolution 2448. New York. United Nations, 13 December 2018.

UN. S/RES/2499. Resolution 2499. New York. United Nations, 15 November 2019.

UN. SC/12010-AFR/3198-PKO/514. Security Council Press Statement on Sexual Exploitation, Abuse in

Central African Republic. New York: United Nations, 18 August 2015.

UN. ST/SGB/1999/13. Secretary-General's Bulletin: Observance by United Nations forces of international humanitarian law. New York: United Nations, 6 August 1999.

UNDP, Human Development Report 1994. Oxford: Oxford University Press, 1994.

von Billerbeck, Sarah. Whose peace? Local ownership and UN peacekeeping. Oxford: Oxford University Press, 2016.

Zahar, Marie-Joelle, Mechoulan, Delphine. "Peace by Pieces? Local Mediation and Sustainable Peace in the Central African Republic.” International Peace Institute. November 2017. https://www.ipinst.org/wpcontent/uploads/2017/11/1701_Peace-by-Pieces.pdf 